ISBN-978-93-86878-24-3

14th LISBON International Conference on Agricultural, Biological, Environmental and Medical

Sciences (LABEMS-18)

Lisbon (Portugal) Dec. 17-19, 2018

\title{
Anatomical Study of Species Ipomoea carnea Jacq. (Convolvulaceae) in Iraq
}

\author{
Aseel Fouad AL-Hussaini and Israa Kareem Nasrullah ${ }^{1}$ \\ ${ }^{1}$ Department of Biology, College of Education for Pure Science (Ibn Al-Haitham), University of Baghdad, \\ Baghdad, Iraq \\ (Email: aseelalhussaini84@gmail.com)
}

\begin{abstract}
The current study included the collection of soft samples for Ipomoea carnea Jacq. The anatomical properties of the leaf, which included the characteristics of the surface epidermis, the vertical section of the leaf, the transverse section of the petiole, the pedicel and the indumentum, as well as the study of leaf venation, were examined
\end{abstract}

Keywords: Ipomoea carnea Jacq., Anatomy, Convolvulaceae

\section{Introduction}

THE species I. carnea belongs to the Convolvulaceae family, which comprises (50) genus and more than (1200) species distributed in moderat and warm areas. It is represented in the Iraqi flora by (27) wild species and (7) cultured species. The species of this family economic importance, including the ornamental plants, which is the source of sweet potatoes (sweet tuberous roots eaten cooked to contain a high percentage of sugar and starch) some of which are harmful plants including Cuscuta spp., that grows parasitical on clovar and other plants [1]. The leaves are slightly purgative, a latex in the plant is used to treat skin problems, and the leaves-cooked and eaten as a vegetable even though they are slightly purgative [2]. The species has several local named, including pink morning and bush morning glory [3].

Ipomoea genus is the largest species of the family and has (700) species [4], and there are trees, bushes, herbs and digitalis flowers form [5]. As for the anatomical studies about this genus, [6] study included the anatomy of wood and stem for some of the family orders including the genus Ipomoea, and examined the secretory compositions of I. asarifolia species by [4]. [7] studied the anatomy of the leaf for some family species as well as [8] explained the importance of anatomical properties in classifying selected species of Ipomoea genus in Sudan, and studying [9] about I. carica L. species..

\section{Materials and Methods}

\subsection{Study of surface epidermis of the leaf:}

The epidermis of the soft samples was studied that were collected directly from the field. The method of replica method was used which mentioned by [10], and placed on a glass slide then studied the stomata and the cells of the leaf after that measure their dimensions and the stomata index was measured according to [11] by the following equation:

Stomata index $=($ Number of stomata $) /($ Number of stmata + Number of ordinary epidermis $) \times 100$. 


\subsection{Study of the vertical sections of the paper and the review}

This study depended on the method of manual cutting using a razor blade, as the plant parts that were 3-4 cm long on a glass slide under the anatomy microscope were fixed and cut into very delicate sections. Then the sections were stained with the Safranin-glycerine by adding one drop of Safranin stain with a concentration of $0.5 \%$ to fifteen points of glycerine. Then transported to a clean glass slide and covered with a glass cover slide [12].

\subsection{Clearing of Leaves}

The ordinary leaves of the species under study to know the system of venation in it, followed method of [13] with some modifications as mentioned by [14] represented by the following points:

a- Samples of the previously collected soft samples were selected, leaving them in the air to dry for 36-48 hours.

b- The leaves were placed in petri dish suitable for the species leaves under study, then added to each petri dish solution consisting of $50 \mathrm{ml}$ of industrial bleach $+50 \mathrm{ml}$ of distilled water and left in petri dishes containing the samples of 24-48 hours to get rid of chlorophyll pigment permanently and then the leaves became completely transparent and thin.

c- The leaves were washed with distilled water several times to get rid of the solution of the bleach, then transported to two concentrations of ethyl alcohol (50\% and 70\%) respectively, for 10-15 minutes each to remove residual water inside the leaves, the last alcohol, with a concentration of $70 \%$ of the petri dish containing the ordinary leaves, was poured.

d- The dishes were added to a few of the tincture of Safranin, and the stain was left for 45 minutes on the leaves in petri dishes until the stain punctuated in the veins of the leaves completely.

e- The leaves are transported to petri dish containers on an absolute ethyl alcohol for 5 minutes.

f- The leaves were then moved to another dish with an equal solution of ethyl and xylene of 1:1 for one minute.

g- The leaves were transported to petri dish containers on pure xylene and left for 30 minutes for clearing.

h- The leaves were photographed and ready for study.

\section{Results}

1. The surface view of epidermis: The current study showed that the leaves were of the Amphistomatic type as the stomata spread to the upper and lower surfaces, but were more numerous on the lower surface. The forms of the stomata ranged between oblong-narrow elliptical and the guard cells with an oblong reniform a single type of stomatal apparatus, parallel paracytic type, has been observed, and the subsidiary cells only (2), and this is consistent with the studies of $[4,7,15]$ that the stomatal type is parallel to this genus.

The dimensions of the stomata on the upper surface ranged from 28-31 $\times 2.8-6.5 \mu \mathrm{m}$, while the dimensions on the lower surface ranged from $22-28 \times 2.8-6.5 \mu \mathrm{m}$, and the stomatal index was 14.5 and 19.8 on the upper and lower surfaces respectively.

For normal epidermis cells, they have anticlinal and straight walls, the inner tangential wall and outer tangential wall walls are semi-straight on both surfaces. The dimensions of the ordinary epidermis cells ranged on the upper surface $28-42 \times 25-39 \mu \mathrm{m}$, but on the lower surface, it amounted to dimensions 36-56 $\times 25-34 \mu \mathrm{m}$ (plate 1). 

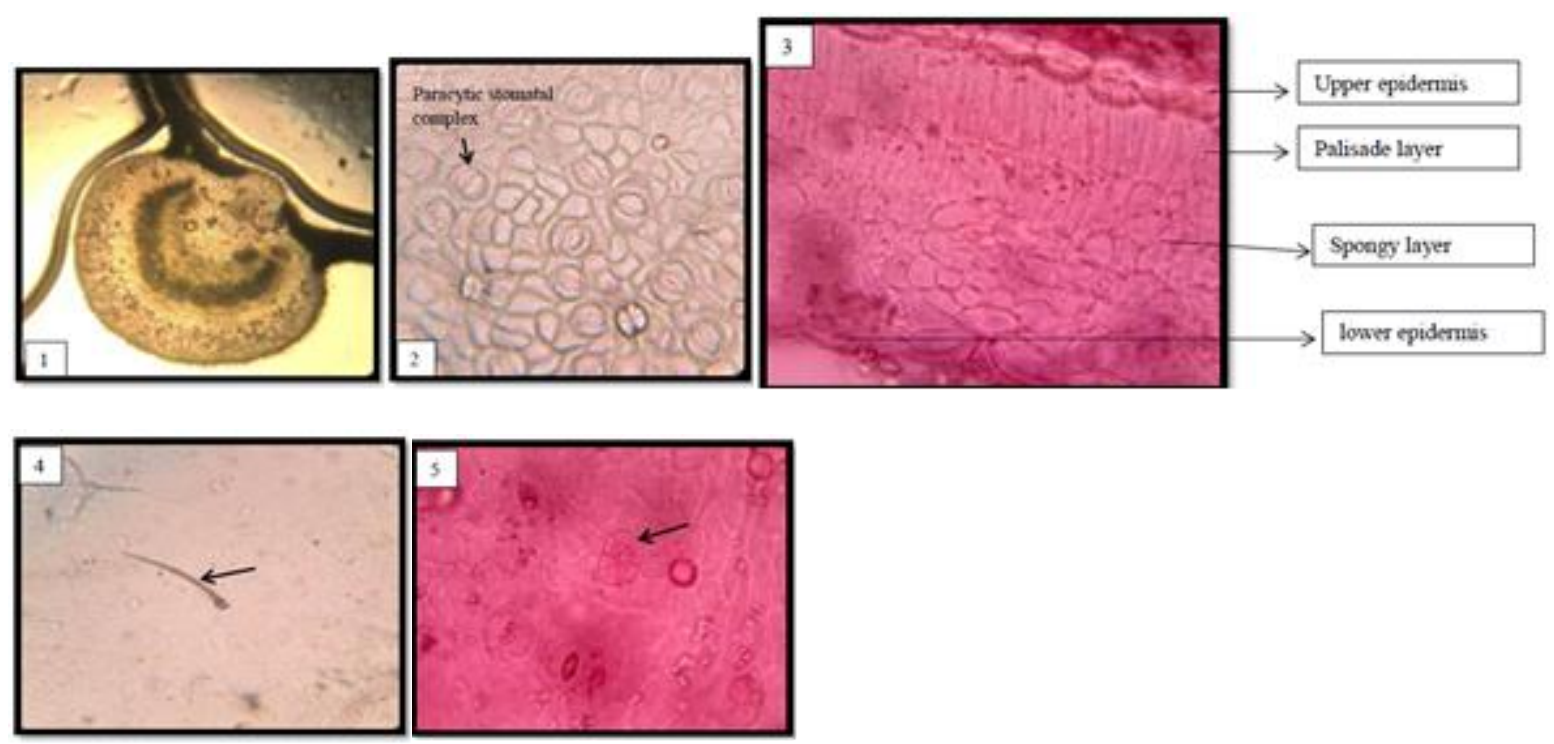

Plate.1: 1-Vertical section of the leaf showing the area of the midrib, 4X, 2-Surface epidermis of the leaf, 10X 3-Cross section to the blade of the leaf, 10X, 4-A glandular hairs, 10X, 5-Glandular hairs 40X.

2. Vertical section of lamina: The current study showed that the upper and lower epidermis cells are almost identical, and the upper epidermis is uniseriate consisting of a single row of cells with ovate-oblong often, varying in sizes and ranging in thickness between (22-28) $\mu \mathrm{m}$. The cells from the outside are surrounded by a thin layer of the cuticle which is striped and this corresponds to the study [8] that the cuticle is striated, and the mesophyll tissue is a bifacial with a high palisade parenchyma and spongy parenchyma. The palsied layer is made up of two rows of compact columnar cells with a thickness of (84) $\mu \mathrm{m}$ and the druses crystal spared between them and followed by several rows of semi-spherical cells are somewhat compact and the thickness ranged between (98-112) $\mu \mathrm{m}$, representing the sponge layer. The vascular bundle of mid rib took a crescent shape and reached a thickness of (98) $\mu \mathrm{m}$. The number of rows of wood (20-22) and the number of wood elements in each row (2-4), and the vascular bundle is surrounded by large thin-walled parenchyma cells on both sides of the upper and lower. The lower epidermis has ranged in thickness (22-31) $\mu \mathrm{m}$ and consists of a single row of cells of a fairly large size, ovate-oblong shape.

3. Cross section of petiole: The cross section took a circular form, as the section showed a continuous layer of small-sized cells, varying in shape representing the layer of epidermis (22 to 22) $\mu \mathrm{m}$ and surrounded the epidermis from the outside with a thin and striated layer representing the cuticle layer. The cortex area followed the epidermis area, which has a thickness rate of (680) $\mu \mathrm{m}$ and consists of (2) rows of collenchyma cells directly beneath the epidermis, followed by (1-2) row of collenchyma cells giving support and attribution to the plant part, followed by (5-8) row of the semi-spherical parenchyma cells increasing in size inward and are of the intercellular space. Followed by (5-8) row of semi-spherical parenchyma cells whose sizes are increasing inward and are of an intercellular space, and it is noticeable that there are a large number of druses crystal between the parenchyma cells and the presence of secretory ducts in the cortex area. The presence of druses crystals corresponds with the study $[6,8]$ and the presence the secretory ducts correspond with the study of [4] about the presence of these secretory ducts in the species I. asarifolia. Followed by the cortex area, the vascular cylinder area consisting of a large and crescent-shaped vascular bundle with a length of $2500 \mu \mathrm{m}$ and a width of (300) $\mu \mathrm{m}$ plus (7) separate vascular bundles with a thickness rate of $(250) \mu \mathrm{m}$, knowing that the vascular bundles are bicollateral bundles. This is consistent with [4] and the leaf is characterized by a pith-free, which is hollow (plate 2). 


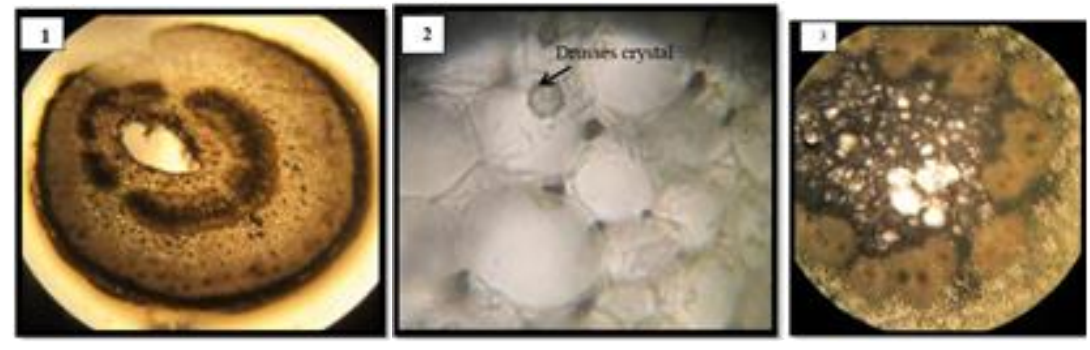

Plate. 2: 1-Cross-section of the petiole, 40X, 2- Petiole cortex, 10X, 3-Part of the cross section of the pedicel of leaf, 10X

4. Cross section of pedicel: The study of the cross sections of the pedicel for the species under study, which was taken from the center area, showed that it was circular shape, and the sections of the species showed one row of small, semi-oval continuous cells representing the layer of epidermis that reached (17-28) $\mu \mathrm{m}$ and surrounded the epidermis from the outside with a thin layer of cuticle. The epidermis area is followed by the cortex area, which has a thickness rate of (480-900) $\mu \mathrm{m}$, and consists of (2-3) row of medium-sized spherical to semi-spherical collenchyma cells, followed by several rows of semi-spherical parenchyma cells that are confined between them intercellular cells. It is noticeable that there are a number of druses crystals within the parenchyma cells.

The epidermis area, the vascular cylinder area consist of (14) is followed by a semi-discrete vascular bundles with a thickness of (200-250) $\mu \mathrm{m}$, knowing that the vascular bundles are bicolateral bundle. The pith area is composed of loose cells that are confined by areoles large size.

\section{Indumentum}

The indumentum that covers the plant parts in the species under study consists of a glandular tapered hair unicellular or bicellular, broad-based articulated with long peripheral cell and the long of a glandular hairs 75.5$103.5 \mu \mathrm{m}(14.56) \mu \mathrm{m}$. These hairs are found on different plant parts sitting on the surface of the leaf and form the head of many cells, the head diameter (33.2), which corresponds to the study [8] in their study of several species of genus Ipomoea including species I. carnea and noted the presence of these two species of capillaries in the species mentioned.

\section{Leaf venation}

The leaf has a pinnately reticulate as the blade penetrates into one midrib vein, stretching from the blade to the top, with secondary and tertiary veins. The venation from the brachidodromous type, as the secondary veins meet near the edge together in a series of brackets according to the Hickey [15] division, and with the size of the primary vein is of the stoud type it is $2.8-3.9 \%$ and the size is calculated by the following equation:

$$
\frac{V W}{L W} \times 100
$$

Whereas:

$\mathrm{Vw}=$ vein width

$\mathrm{Lw}=$ leaf width

The venation is thick as the ratio of $2-4 \%$ and secondary veins straight to semi-straight, secondary veins contact with the midrib is of the moderate type $\left(45^{\circ}-65^{\circ}\right)$, and the effects of aeroles are irregular (random), and the ends of the veinlets is a complex form of multiple times. 


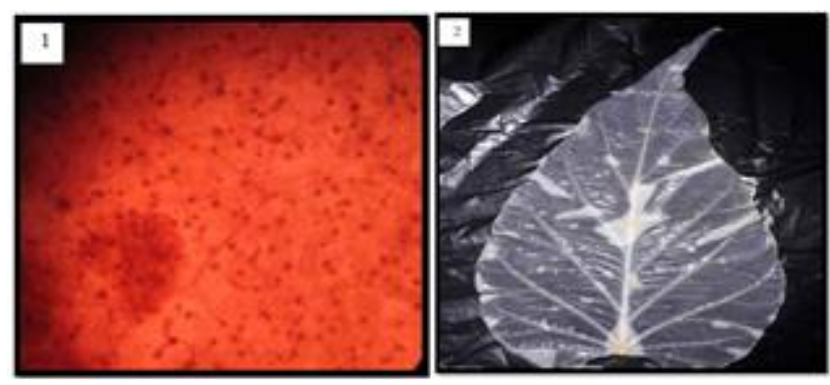

Plate.3: 1- Areoles, 10X, 2-leaf venation

\section{References}

[1] Y. B. Al-Katteb "Classification of seed plant, first edition, Dar al-Kutub for printing and publishing", University of Mosul, 1988: 592 pp.

[2] http://en.m.wikipedia.org.

[3] http://tropical.theferns.info/view.tropicalphp?id=Ipomoea+carnea.

[4] F. M. Martins, J. F. Lima, A. A. Mascarenhs, T. Macedo, T. "Scretory structure of Ipomoea asarifolia Desr. Roem of schult. Anatomy and histoche stry", Braz. J. Pharmacogn.., 2012, 22(1), 1-9 pp.

[5] http://www.brianica.com/plant.convolvulaceae.

[6] S. Carlquist, Sherwin, M. Hanson, Michael. (1991). Wood antoms of convolvulaceae. Aliso. J. System. Evolution. Bot., 1991, 13(1), 51-94 pp. https://doi.org/10.5642/aliso.19911301.03

[7] S. K. Tayade, D. A. Patil, D. A. "Foliar epidermal inverstigation in some hitheto unstudied convolvulaceae", II. Curr. Bot., 2011, 2(9): 26-30 pp.

[8] I, Madani, M. Majbour, "Important of anatomical feature in the taxonomy of selected plants species from the genus Ipomoea (Convolvulaceae) in Sudan”, Sudan J. Sci.., 2017, 9(1), 25-37.

[9] S. Chaudhyry, C. Rohman, H. Choudhury, M. Sudhend, "Studies on Ipomoea carica L. sweet apromising ethnomedicinally important plant", J. PBS., 2015, 2(4), 378-395.

[10] Y. M. Ahmed, Y. M. "Effect of air pollutants on Kirkuk cement factory in the growth of some ingredients of some cultured and natural plants", PhD thesis, University of Baghdad, College of Education (Ibn Al-Haitham), 2016, 149 pp.

[11] T. A. Al-Khazraji, F. M. Aziz, "Practical in anatomy of plants and microscopic preparations", Press of the Ministry of Higher Education and Scientific Research, Salahuddin University, 1989, 321 pp.

[12]Z. A. Esmaeel, "Comparative anatomy of some wild dicots spp. Grow in in Baghdad province", PhD. Thesis. Baghdad university college science. Department if biology. Iraq, 2009, $111 \mathrm{pp}$.

[13] N. M. M. Al-Obeid, "A taxonomic study of genus of the Chenopidaceae family in the northern and central regions of Iraq", PhD thesis, College of Education. University of Tikrit, 2013.

[14]B. M. R. K. Al-Obeidi, B. M. R. K. "Comparative anatomical study of vegetative parts and some reproductive parts of Cucurbitaceae family in Iraq", MSc Thesis, College of Education for Pure Sciences (Ibn Al-Haitham), University of Baghdad, 2014, 163 pp.

[15] C. R. Metcafl, L. Chalk, “Anatomy of dicotyledons”, Vol. III. Clarendon press Oxford. England, 1950.

[16]L. J. Hickey, "A revised classification of architecture of dicotyledons" 2nd ed. of dicotyledons leaves in Metcalf, C. R. \& Chalk, L. (eds.). Anatomy of dicotyledons Vol. 1 edition pp: 25-39. Clorendon press Oxford, 1979. 